\title{
Understanding The Diversity of Madrasah Aliyah Students in Gorontalo
}

\author{
$1^{\text {st }}$ Mujizatullah ${ }^{1}, 2^{\text {nd }}$ Abu Muslim ${ }^{2}$ \\ \{mujizatullah@kemenag.go.id ${ }^{1}$, abumuslim.litbang@gmail.com ${ }^{2}$ \} \\ Balai Penelitian dan Pengembangan Agama Makassar \\ Jl. AP. Pettarani No. 72 Makassar ${ }^{1,2}$
}

\begin{abstract}
This study aims to find out in depth the diversity values that are understood and practiced by students at Madrasah Aliyah Negeri 1 and Madrasah Aliyah Al Huda in Gorontalo City which are associated with SARA (ethnicity, religion, race and intergroup). This research was conducted using qualitative methods. Data were collected through interviews with students and teachers, as well as observation by directly observing activities related to diversity. The results showed that the madrasa students came from various schools of religious understanding, ethnicity, race and culture had understood and implemented tolerance well. The curriculum applied by Madrasahs can also provide space for understanding diversity for students. The exploration of the understanding of the Diversity in MAN 1 and MAS Al Huda was also obtained from the Intracurricular and Extracurricular teaching and learning activities. Intracurricular activities are obtained from subjects related to the understanding of diversity, and extracurricular activities are obtained from several activities including Islamic spirituality, PASKIBRAKA and scouts. In addition, Madrasah incidental programs or activities that can provide space to implement diversity include activities at the Ministry of Religion Anniversary event and art competitions in 27 provinces. Students' understanding of diversity is also obtained from social media and literature books to enrich their insights regarding learning material obtained at Madrasah.
\end{abstract}

Keywords: understanding diversity, students, madrasah aliyah, SARA.

\section{Introduction}

Indonesian society has the characteristics of a pluralistic society consisting of cultural, ethnic, religious and racial diversity. Diversity exists in various spaces of life. Pluralism that occurs in the social group of the people of a country and small group communities, such as individuals in one household adhering to a different religion. Religion has become a guideline for human life should have lived peacefully with different religions. (Setiadi, et al., 2006: 142).

Diversity is a treasure of the nation's culture but can become a potential conflict when it cannot be managed properly and must be able to respond proportionally. Various cultural and racial conflicts due to a lack of understanding of pluralism so that religion is expected to be able to bridge and accommodate the diversity of individuals. Students are expected to be able to minimize group and inter-religious, ethnic, religious and cultural conflicts through the study of religious harmony, the doctrine of holy books, regarding the teachings of harmony in their respective religions (Sudjangi, 1998: 3). 
Students have recognized the reality of the diversity of various tribes that are scattered along the islands of our country, the introduction of students only to large tribes, as is usually accepted in school learning. Meanwhile, the small tribes that have a way of life and beliefs that are different from the general public, are almost unknown. This is what causes negative views often appear, when information about a tribe that students have never known so far, especially among people who have been marginalized in the name of faith and ethnicity. This makes it easy for suspicious views, stereotypes and prejudices to emerge. A point of view that will lead to intolerance at school, but ironically, the students are still limited to general matters. They are more familiar with KPOP culture, as stated by David Chaney (1996: 43).

Lack of understanding of tolerance in the realm of education will have a serious impact on the harmony of the lives of young people in the future, including students who are still teenagers. The pluralism that has been destined should be realized by students with attitudes and actions that uphold pluralism on the principles of equality, equality and justice.

The understanding of diversity should be instilled by all educators in the school, including these religious educators. From there we hope that students will have an awareness of the differences that exist. Provide space for minority groups to express themselves freely and without intimidation. It also encourages students, the majority of both ethnic and religious groups, to have moderate attitudes and have a peaceful perspective.

In an effort to form a comprehensive and comprehensive understanding of religious diversity, the government has issued Presidential Decree No.22 of 2015. The regulation states that religious education institutions must be the main basis for instilling religious diversity education, by prioritizing the formation of a national mindset and strengthening the ideology of Pancasila. This is because the characteristics of the Indonesian nation are multiethnic and multi-religious and multicultural (Ismail, 2012: 55) but the understanding of the diversity of students is decreasing.

Based on the results of the above reality, it is necessary to carry out further research regarding the understanding of the diversity of students in madrasas, even though in madrasas it is single (only Islam) including the existence of mazhab (Islamic internal flow) that develops among students. The problem in this research is how to understand the diversity of students in Madrasah Aliyah ?. While the sub-problem is how to understand and apply and expect students to diversity in Public Madrasah Aliyah and Private Madrasah Aliyah related to SARA (ethnicity, religion, race and intergroup).

\section{Literature Review}

The results of the 2016 Research and Development of Religion in Makassar regarding students' perceptions of radicalism show an increasing tendency of students who do not want to build relationships with other religions. For example, they don't want to be friends and don't want to congratulate you on religious celebrations, friends of different religions. This case reached $60-80 \%$ of respondents.

Meanwhile, the results of other research and development of Religion in Makassar in 2009 showed that in the context of religious attitudes, the average student was quite moderate. Even the majority of students also reject violence in the name of religion, around $70 \%$ also stated the need for tolerance between religious communities (Ismail, 2009: 129-134).

Supporting these findings, the research results of the Makassar Research and Development Center for Religion in 2019 regarding the insight of the diversity of religious educators and students at SMP 1 East Tomini show that students have understood and been able to apply tolerance between religions and groups both at school and outside of school. 
Shofa (2016) says that Pancasila is the ideology that unifies the nation and is a solution to the conflicts that occur between nationalist and religious groups. Meanwhile Hartoyo (2010) in his research concluded that openness to others is an important requirement to capture ethnocentrism. Furthermore, Anwar (2018) states that from an Islamic point of view, difference is a nature, which is then implemented by Indonesian Muslims in the life of the nation and as a homeland.

Lestari (2015) provides an overview of the results of his research that a study of cultural diversity not only provides a comprehensive picture but more than that, can foster a dialogue of perceptions of racial harmony in the midst of national life. Multiculturalism is a given from God, but Bineka Tunggal Ika is a gift from our ancestors that must be preserved and preserved.

The Last, Suparlan (2003) provides an illustration that national integration offers a model of multiculturalism in understanding diversity that emphasizes equal cultural diversity. The author emphasizes that the multiculturalism model can only exist and develop in a society that upholds the principles of democracy, the rule of law, and also the eradication of corruption and collusion.

\section{Understanding the Diversity and Nationality of Students}

Understanding is a process, an act and a way of understanding. Meanwhile, in Bloom's taxonomy, "the ability to understand a higher level than knowledge". The understanding of diversity in Bloom's taxonomy research refers to Retno Utari which is meant for cognitive, understanding and application (Utari, 2016: 13).

Meanwhile, the definition of understanding according to Anas Sudijono (2010: 50) is knowing about something and being able to see it from various aspects and is a level of thinking ability which is a level higher than memory and memorization. Meanwhile, according to Yusuf Anas (2009: 151), what is meant by understanding is the ability to use knowledge that has been memorized more or less the same as what has been taught and in accordance with the intended use.

From the above opinion, the indicators of understanding are basically the same, namely by understanding something means that someone can defend, distinguish, suspect, explain, interpret, estimate, determine, expand, conclude, analyze, give examples, rewrite, classify and summarize. This indicator shows that understanding contains a broader or deeper meaning than knowledge.

If it is associated with students, according to Langgulung (2003: 102) understanding is interpreted as human interaction in humanitarian networks. In human interaction we will encounter diversity. Humanitarian relations with various religions, ethnicities and races. The same thing was conveyed by Haitami Salim (2012: 24). From this view, it is clear that the understanding of students must be seen in the daily implementation of students.

Understanding diversity is an effort to provide understanding and form tolerance for religious, ethnic, racial and cultural diversity (Suardi, 2015: 55). To find out the understanding of the diversity of students, it can be seen in the understanding of the learning material received and also their attitude towards different religions. In fact, a religious educator who has insight into diversity to develop an attitude of tolerance and peace in students (Harahap, 2011: 78).

Understanding diversity can be seen in the learning materials obtained by students, and their attitudes towards the diversity of religious traditions and religious diversity to instill understanding and tolerance for religious harmony (Harahap, 2011: 78). 
National integrity is based on the understanding of nationality which according to Suhady and Sinaga (2006: 24) has 6 dimensions of the basic value of national insight: manifested in national unity and integrity, namely: First, respect for human dignity as a creature of God Almighty. Second, a shared determination to live a free, independent and united nation. Third, love for the motherland and the nation. Fourth, democracy and people's sovereignty. Fifth, social solidarity. Sixth, just prosperous society. There are 4 pillars in the life of the nation and state in Indonesia, namely; Pancasila, UUD 1945, NKRI, and Bineka Tunggal Ika.

\section{Research Methods}

This research is a descriptive case study using qualitative methods. Research is intended to provide a systematic and accurate description of factual facts and characteristics of certain populations (Zuriah, 2005: 14). Descriptive research can also be called exploratory research, namely for exploration and clarification of a social phenomenon or reality, by describing a number of variables relating to the problem or unit under study. (Faisal, 1999: 200). This research will describe the attitudes and knowledge of madrasah aliyah students regarding their understanding of diversity.

The object of this research is Madrasah Aliyah Negeri 1 and Madrasah Aliyah Al Huda in Gorontalo City. The research targets are students, the head of the madrasah and the teacher at the madrasah. The research data consisted of primary data and secondary data. Primary data were obtained from direct interviews with Madrasah Aliyah student informants who were also related to this study such as the head of madrasah, teachers, or education observers. Secondary data is research supporting data obtained indirectly from informants, usually in the form of documents or articles related to research, such as madrasah data from the local Ministry of Religion or data on the description of research locations from the local Central Bureau of Statistics.

The primary data collection technique is done by using semi-structured interviews. Interviews were conducted to explore in depth the understanding, perspectives and implementation of the diversity of students in Madrasah Aliyah Negeri 1 and MAS Al Huda Kota Gorontalo which are related to 1) Racial Diversity; (2) Ethnic diversity; (3) Religious Diversity; (4) Cultural Diversity.

Data processing and analysis was carried out using a qualitative matrix related to understanding the diversity of students, the perspective of student diversity, the implementation of the diversity of students, including support for educational and teaching programs oriented towards the diversity of students in madrasah.

\section{Results and Discussion}

\section{General Description of Diversity in MAN 1 and MAS Al Huda in Gorontalo City}

Madrasah Aliyah Negeri 1 and MAS Al Huda are both the leading Madrasah in the State and the private sector in Gorontalo City. MAN 1 which is located on Jl. Poigar No. 26 Kelurahan Molosipat, Sipatana Subdistrict, with a total of 1003 students of MAN 1 Gorontalo City consisting of 326 men and 678 women in 32 study groups. Meanwhile, Madrasah Aliyah Al Huda is located on Jalan Muhammad Yamin III No.9 Limba B Sub-district, Kota Selatan District, Gorontalo City. The students from the madrasah consist of ethnic Gorontalo, Balinese, Javanese, Tator, Buginese, and Makassarese. The number started 275 people and the 
religions practiced by the students were all Muslims. The embodiment of the diversity of madrasah aliyah students is enriched by the existence of the Intra Madrasah Student Organization (OPDIM). These two madrasas clearly illustrate the reality of diversity.

Research on the understanding of diversity in the two madrasas was carried out by observing the reality of diversity accompanied by an understanding of diversity from school members, especially those that will be highlighted in this paper, namely that students are seen in the learning process carried out in the cognitive domain at the level of knowing, understanding and applying. This madrasa is facilitated by a place of worship in the mosque. The five daily congregational prayers are routinely held at the venue, including extracurricular activities, namely a seven-minute lecture. Cultural activities are intended as a forum to hone the ability of students to lecture on religious themes, one of which is understanding the diversity of students.

\section{General Understanding of Diversity by Students}

Understanding the diversity of students basically has the seeds of implementation in him. This can be seen from the ability of students to re-explain the material related to intracurricular and extracurricular materials that have been obtained from subjects related to diversity. Extracurricular activities are carried out together with friends at madrassas, for example Islamic spiritual activities, in these activities there are various kinds of schools or schools of thought; Wahdah, salafih, tabliq congregation, NU, Muhammadiyah, and activities outside the madrasa are carried out in the form of paskibraka training involving interfaith students (Hindu Christianity, Buddhism).

Joint activities carried out by students from other religions are extracurricular activities involving students at the madrasa and students from outside the madrasa consisting of various religions. From the observations of researchers when students tell stories about these joint activities, it can be seen that the form of cooperation from various students of different religions in post-line training, for example, they look harmonious and respect each other between religions.

Here the orientation of diversity can be seen from the familiarity of students with each other even though they are of different ethnicity, religion, race and culture, but they still respect each other. This is a reflection of a personality that loves differences, does not look at someone when they are good friends of race, ethnicity and religion, are friends with many people without seeing differences. Even though the differences are still one, complementary even though we have different languages, we must try to be able to understand the language of other tribes. (Interview with Ronaldi Nani, Chairman of OPDIM MAN 1 Gorontalo, February 20, 2020).

Students' understanding of diversity is also obtained from the subjects of Al-Quran and Hadith. Students seem to have a very good understanding of and even practice the main contents of the Al-Quran letter Al Hujarat verse (13) regarding the diversity of tribes and nations, "in fact we created men and women and made you tribes and nations to know each other and know each other and indeed the noble beside me is a pious person". They get used to living with tolerance with different sects of different religions, respecting each other, please help in matters of goodness.

Students' understanding of diversity is obtained from the Akidah Akhlak subject. Akidah lessons to understand the Akidah, principles, insight into the diversity of schools or differences in understanding in the Islamic creed as a basis for the practice of inclusive faith in everyday life, understanding the various kinds of tawhid such as tauhid uluhiyah, tauhid rububuyyah and their implications in life daily. Moral lessons, provide an understanding of 
noble morals and avoid reprehensible morals and are implemented in everyday life both in Madrasah and outside Madrasah (social environment). (Interview with Muhammad Fajrin B. Dunggio, Chairperson of PASKIBRA MAN 1 Gorontalo, February 29, 2020).

Insights on diversity are also obtained from the subject of Fiqh, in the material on the aspects of worship and Muamalat, regarding the principles of worship and Shari'a in Islam: Fiqh Ibadah, Muamalat, and Munakahat. Understand and apply the sources of Islamic law in everyday life as a manifestation of the balance of human relations with God, fellow humans (knowing and understanding the diversity of religious understandings of other schools so that they do not think that their understanding of the sect is the most correct, human relations with other creatures or their environment. Interview with Nazzul Hilmi Biki, Chairman of RAMAPALA MAN 1 Gorontalo, February 29, 2020).

One of the students' understanding of diversity based on general knowledge was obtained from the subjects of Sociology class X and XI, majoring in Social Studies regarding Multicultural material, material social symptoms, cultural change. Conflict and how to resolve it, material for solving problems of conflict between religions, countries, ethnicities / ethnicities by providing examples of class XI. Sociology lessons are the key to self-learning, interaction with others about tolerance. Anthropology, the material is Culture, Cultural diversity, Languages, Dialects, oral traditions. A concrete example is that art in Bali is more religious in nature, where certain statues are worshiped that have an influence on religious life (art, culture, religion) that is value. (Interview, Deli, Sociology and Anthropology Teacher Kls X, XI, XII MAN 1 Gorontalo, February 27, 2020). (Interview with Muhammad Rifai Gobel, Head of Languages Programs MAN 1 Gorontalo, 28 February 2020).

Understanding the diversity of students provides motivation for students to start accepting the reality of these differences. Because diversity is sunnatullah, students are expected to accept and be grateful for it. One of the forms of acceptance of diversity is the ability to place oneself on differences in religion, ethnicity, race and culture. The learning process of students towards understanding diversity has led to tolerance (Wazler, 1997), by expressing openness to others, respecting inter-religious communities.

The material above emphasizes that in everyday life students are led to familiarize themselves with mutual understanding, especially in the issue of diversity that creates peace, as well as actions and words that lead to piety to Allah Almighty. The mutual interaction between sects and religions in actions that lead to corruption, hostility, conflict and sinful actions is strictly prohibited in Islamic teachings.

From a series of religious learning material about what was explained by students, it is clear that students not only know about the material, but also very much understand it. This shows that when referring to Bloom's taxonomy, students have reached the level of understanding the material presented. It was also proven that students were able to explain well about the diversity of religious schools of thought in madrasas, including tolerance in the community. Students also often write themes of diversity on their social media pages.

To apply this understanding, students usually motivate their friends to be involved in cooperation between students of different religious schools of thought in the madrasa environment. Students together with friends of different religions, including Christianity, Catholicism and Hinduism who are outside the madrasa design programs that involve multireligious students such as PMR activities and PASKIBRA activities. Furthermore, students take part in cult activities at the mosque which discuss their understanding of tolerance. At that time they could recite some of the verses related to tolerance. Explain about tolerance. They are even able to describe it according to the diversity context they have. In this case, according to Bloom, they are already at the knowing and understanding level (Bloom, 2011). 
Understanding the diversity of students technically is of course also obtained through PPKN subject matter found in the diversity of the Indonesian nation in Class X, Class XI Harmonization of Human Rights and Obligations in the perspective of Pancasila, and Class XII National Democracy System and Dynamics. The material shows how students understand and are willing to put themselves in this diversity. Students began to be encouraged to be tolerant.

Forms of tolerance include mutual respect at religious celebrations and viewing positions that differ from religion or ethnicity to the same as one's own. This material has encouraged students to build active tolerance. This tolerance in the 5 dimensions of Walzer (1997) is in the fourth dimension, namely expressing openness to others, wanting to know, appreciating, wanting to listen and learn from others. In another language, Diana L. Eck calls it pluralism, which is seeing others as having the same position without any differences on the basis of ethnicity, religion or any other classification (L. Eck, 2006: 1).

\section{Curriculum Support in Developing Diversity Understanding}

The Madrasah curriculum that can provide space for students to implement diversity through extracurricular activities including incidental madrasah programs or activities that can provide space to implement diversity, the Ministry of Religion Anniversary, art competitions in 27 provinces consisting of dance and singing, extra-curricular learning, art musical dance drama, songs and dances of all tribes by means of one song that connects from the Sabang to Merauke area. Dhuha prayers in congregation are performed Monday, Wednesday and Friday from 6:45 a.m. to 7:00 a.m.

The creation of religious life in the Madrasa environment, habituation in carrying out worship carried out in Madrasahs are expected to decorate Islamic behavior in the lives of students, the challenges faced are inseparable from the enormous global influence, which has now almost penetrated all aspects of life in the world. . Including information through social media, which can affect student understanding.

Since 2018 until now, habituation has begun to be carried out through the concept of polite speech and dress modesty, mutual respect between ethnic groups, cultures and schools that have developed in madrasas while still following all the rules set forth in madrasas. Guidance for students through lecture exercises at the beginning of Zuhur prayer, the theme of racial diversity and mazhab, and intensified lecture etiquette without insinuating ethnicity, race and understanding of different schools regarding mutual respect between different schools. (Interview with DR. Waris Masuara, S.Ag, M.Hi. Head of Madrasah MAN 1 Gorontalo, 19 February 2020).

Likewise with the MAS Al Huda curriculum which can provide space to understand diversity for MAS Al Huda students obtained from the Intracurricular and Extracurricular teaching and learning activities. Understanding the diversity of students is obtained from intracurricular learning activities from religious subjects including Islamic Cultural History, basic competence to understand, appreciate, and accept differences in ethnicity, religion and race, subject matter regarding the diversity of Arab civilization before Islam in Class X, material of the Muawiah dynasty and Abasiah in Class XI.

This diversity is as the word of Allah in the letter Al Hujarat, which says that Allah created human beings consisting of men and women, and made you tribes and nations to know each other, and to tolerate each other, and other religions. Indeed, the most noble with God is the most pious person. Class XII is reflected in learning Modernization of the Islamic world, in relation to the understanding of the example of the Prophet in appreciating diversity. One example is one time when a Jew died and passed in front of the Prophet's house when he saw 
the Messenger of Allah standing from his seat as an attitude of tolerance towards fellow humans even though their religion was different. (Interview with Suharmin Alinti S.Ag. Teacher of SKI MAS Al Huda, Gorontalo City, February 20, 2020).

The basic teachings of understanding diversity are also found when the KBK (Competency-Based Curriculum) is implemented, where Sociology lessons are taught in all science, social studies, religion and language majors. One of the sociology learning materials is social problems in society, particularism and exclusivism. Also in the Anthropology Lesson, the material includes Culture, Cultural diversity, Language, Dialect, oral traditions (Interview, Deli Teacher of Sociology and Anthropology Kls X, XI, XII MAN 1 Gorontalo, February 27, 2020).

\section{Madrasah Policies in Supporting the Development of Diversity Understanding}

Madrasah policies related to respecting the diversity of students and teachers in particular do not yet exist, but activities regarding the diversity contained in ROHIS are the translation of the vision and mission, namely organizing academic and non-academic activities in a balanced way to achieve achievement and make MA as a center of excellence in science based on 5 cultures work; integrity, innovation, professionalism, responsibility and exemplary.

Global development including the understanding of the diversity of SARA (ethnicity, religion, race and intergroup) has triggered the emergence of various demands in all sectors of development, including the involvement of the education sector, because it has an important contribution in determining the direction of the birth of civilization which is very much needed in building the order of life of the people. sustainable, then the vision and mission as an orientation that is the target of achievement is very important to be formulated and then implemented in every institution, including MAN 1 Gorontalo which is an integral part of the development of the education sector, the formulation of the vision and mission and goals was born with reference to the standard of good interests related to interests. students and society. Build interactive communication between madrasahs with the parents of students and the community in the context of developing madrasas through regular meetings every semester.

The experience of the teacher facing students who have fanatical schools of thought (Salafi). The English teacher when teaching song (singing) material, students at that time did not want to sing because they thought that by singing their memorization of the Quran could be lost and the student to be replaced with nasyid religious chants, they did not want to in front of friends so ask in a special room. In addition to this, students did not want to take off their caps, women with masks initially wore a veil because it was forbidden to replace them with masks.

In 2017 there were students wearing short pants but now it is banned. Salafis are not allowed to pray Dhuha in congregation, they have the belief that the sunnah is done individually. Furthermore, in 2017 there were students who came to the mosque to make a circle behind the hijab as a barrier to listen to the tausiah from the ustaz which was held at 3 $\mathrm{pm}$ and at that time it was organized but for now it is no longer allowed because there is already an extra-curricular activity called Rohis. (Interview with Mayke, Spd, M.Pd, Kamad Representative of the MAN 1 Gorontalo Curriculum, February 20, 2020).

The way students use social media for the introduction of religious diversity is carried out after school because students are prohibited from using cellphones. Students use digital literacy about diversity, namely literature on religious pluralism. Furthermore, for the introduction of diversity, join in ROHIS by introducing several schools and sharing the knowledge conveyed by students and coaches from different schools, namely Salafi, Wahdah, Jamaah Tablig, NU and Muhammadiyah. 
Madrasa regulations or policies related to respecting the diversity of students from various schools including the Salafih, Jamaah Tabliq, Wahdah and Assunnah Al Huda Gorontalo Islamic Education and Da'wah Foundation at the time of admission of new students there is a diversity of students, so the foundation's policies when teaching and learning activities begin from 07.00 WITA until school time all students are instructed to adjust beforehand not to wear the veil. If there are students who wear the veil, they can only wear it after school. Because the madrasah policy during teaching and learning activities students must follow the uniform dress regulations at school. Likewise, PKL participants from IAIN who wear the veil still have to adjust when they enter the madrasah by following the regulations that have been announced. (Interview with Suharmin Alinti, S.Ag., Head of MAS Al Huda Gorontalo, 20 February 2020).

The diversity of its relationship with Madrasah Culture is the rules that apply and must be obeyed by every student of MAN 1 Gorontalo City. in order to create an atmosphere and madrasa culture that can support effective learning activities, to improve the attitudes and behavior of good students, and to create a safe and comfortable madrasah environment in taking education to create polite and accomplished students. Rules for Students at Madrasah Aliyah Negeri 1 Gorontalo regarding Student Development based on KMA No. 184 of 2019 concerning Guidelines for Implementing Curriculum in Madrasas, which basically is also one of strengthening the understanding of diversity.

The understanding and practice of diversity is obtained from literature books that are commonly read in relation to diversity in PPKN textbooks. However, the development of diversity literacy was later expanded by not only making the PPKN book a delinquent textbook. Teachers also often use Supporting Books in order to strengthen the strengthening of moderate religious understanding, including by inviting students to read Fiqhi, Alquran Hadith and Akidah Akhlak, Fadhilah Amal, Fadhilah Sadokah, Hikayatus Sahabah, Mubakhas Hadith (Interview with Muazman AP. Ibrahim, Head of School Security Patrol, MAN 1 Gorontalo, February 28, 2020).

The life experience of the diversity of students in madrassas, is also done by updating from social media and some moderate websites. Students are directed so that in searching for sites or religious lessons, they must read carefully or ask someone who knows better, before making them a reference. If in the school environment we can tolerate each other, if there is a problem or something the students don't know, we ask the ustadz and ustadzah who know about the problem.

In the community or at home, understanding diversity is also done through an organizational platform. In general, their activity there makes them a person who is quite tolerant of differences in ethnicity, religion and race. For example, if there is a Christian neighbor in the vicinity, he must help him, and if he sees another understanding that is not the same, immediately ask the ustaz who knows better, and is tolerant enough to the understanding he holds.

This is a direct implementation of the teacher's lesson related to intercourse between people even though they are of different religions and beliefs. The teacher taught that if we hang out in a different religious environment, we should not insult each other, we should help each other when they are hit by troubles because humans are social creatures, but if they worship, we should not join them because our religions are different, for you your religion and for me my religion. (Interview with Rahmat Aditya, MAS Al Huda Gorontalo student, 29 February 2020).

In addition, the teacher also explained the different understandings in Islam. For example, if we find a problematic understanding, we must remember and always increase our 
faith and don't easily follow along. Please pay attention first that if the understanding is different, then we should not immediately blame that understanding but should be investigated further, because our priests used to have different understandings or sects but they respect each other and not blame each other. Other activities related to the coaching of the intracurricular subject olympiad which can be seen from students consisting of several different manhaj. (Interview with Suharmin Alinti S.Ag, Head of Madrasah Aliyah MA Al Huda, 29 February 2020).

Students' understanding of diversity aims to unite the differences that exist in a country, environment / community in order to respect each other and harmonize so as not to be divided. The goal is to prevent a conflict. Realizing the noble ideals of Indonesia to unite the existing diversity. Maintaining the unity and integrity of the nation so that it remains intact and becomes a harmoniously solid nation and so on. Personality who loves differences, because with differences we can share experiences and stories that can add to knowledge, besides that differences can make us a better person. Based on the results of interviews, observations and documentation of Madrasah Aliyah Negeri 1 and MAS Al Huda in Gorontalo City, it shows an understanding of diversity by strengthening the intracurricular and extracurricular curricula with the perspective of religious moderation.

\section{Students' Experience Making SARA as Part of Diversity}

The concept of SARA is generally related to diversity which consists of ethnic diversity, religious diversity, racial diversity and inter-group diversity (culture). The definition of SARA, namely mutual respect or getting to know other followers of religions or beliefs as said by Allah in the Koran that Allah created male and female human beings, nationalities to know each other, not only in general education which explains race, however, even in religious lessons we are organized and taught to know and respect each other. The concept of SARA respects each other by not looking at positions or others and we still respect each other. A concrete example of SARA, learn to respect, so we will be rewarded with small respect for the big and the big respect for the small. As far as possible, students can understand SARA inside and outside the madrasah. In the madrasah students must obey the rules and respect the opinions of others. Interesting experiences when hanging out with people who always invite goodness, for example studying religion in a study or other community at madrassas can make more friends to exchange opinions. Outside the madrasa, it is also hoped that they can mix with different religious groups.

The following are some of the experiences of students that are conveyed as a marker of how they understand SARA as part of diversity. Safna Sadiq stated that: Youtube which is usually watched is more about the experience of hijrah. The experience of SARA which is commonly referred to by teachers, namely race, differences between groups, ethnicity, language and skin color regarding race, skin color does not rule out black people only in Papua and it turns out that they come from their respective descent and region. If white skin is the most prominent in China, it is possible that they are also in Indonesia, such as in Manado. The understanding of SARA in the family environment in religious diversity is the most prominent in the family from the implementation of one day prayer, two days to 40 days on the implementation of the deceased and the prayers of other spirits. There are also racial diversity that is different in the family of skin color, hair and others. My experience through social media is about differences of opinion about religion, ethnicity and culture because each region has different languages. (Interview with Safna Sadiq, Class XI MAS Al Huda Student, 25 February 2020). 
The experience of living diversity in Madrasah, making friends with other tribes and languages, even though we are different, we must not differentiate between friends. We are taught to unite regardless of who we are friends with, even though we are of different ethnicity, race and religion. Bineka Tunggal Ika is different but still one. The experience of diversity in Madrasahs in our ROHIS organization does not make a difference on the basis of different religious understandings. Like Salafis, NU, Jamaah Tablig, we are united because Allah does not see different understanding of religion, we also do not refer to one understanding, for example Salafi understanding, even though salafi understanding is quite dominant in ROHIS. Tolerance respects each other's religions. (Interview with Rahmawati Ikoni, student of MAN 1 Gorontalo activist of Jamaah Tabligh Masturoh, February 21, 2020).

Another experience about diversity in the family environment was shared by Zulhabasiru, although he had attended Wahdah school but was not too fanatical about following the understanding at Wahdah because his parents forbade him, and religious understanding in madrasas today is not allowed to understand or follow religious schools. Tolerance in religion is mutual respect between adherents of other religions, especially respect between adherents of the schools and not insulting each other. The experience of diversity knowledge obtained from PPKN teachers and religious teachers in PPKN subjects contains material about diversity, namely national integration within the framework of Unity in Diversity which is taught in Class X and in Class XI semester II there is material on diversity regarding threats to national integration in various fields. (Interview with Zulhabasiru, Wahda Activist, Class X IPA 5, MAN 1 Gorontalo, February 21, 2020).

Likewise with Adinda Nurfataraini Arif who conveyed her experience in diversity in the family environment, her family background, who are all Muslim, but some come from Jakarta, Manado, make friends with people of different ethnicities. In addition, he also conveyed the experience of diversity in the ROHIS activities that he participated in which could unite several other organizations such as Salafis, Wahdah, and jamaah tablig. ROHIS also teaches him to be able to accept other people's opinions without being forced to join the organizations we join. According to Adinda, religious tolerance is important because with this tolerance we can respect religious differences without forcing other religions to enter our religion. (Interview with Adinda Nurfataraini Arif, student of MAN 1 Gorontalo, Ativis at Wahda via social media, 21 February 2020).

Based on this, the students' understanding of diversity in MAN 1 and MAS Al Huda have understood and implemented diversity with an attitude of respect for one another. This can be seen when interacting at Madrasahs and outside Madrasahs or the community. Cooperation of various students of different religions, as the beginning of the creation of tolerance and harmony both at the Madrasah, environment and community levels so that they can create peace, tolerance and harmony and can treat others with respect, accept differences, and live together peacefully, and mutual respect.

\section{Closing}

The Madrasah curriculum that can provide space to understand diversity for students of MAN 1 and MAS Al Huda is obtained from the Intracurricular and Extracurricular teaching and learning activities. Intracurricular activities are obtained from subjects related to diversity, and extracurricular activities include Islamic spirituality, paskibraka and scouts.

Madrasah Incidental Programs or Activities that can provide space to implement diversity including activities at the Ministry of Religion Anniversary event, art competitions in 27 provinces consisting of dances and chants, extra-curricular learning, musical dance drama 
arts, songs and dances of all tribes by way of one song continue to continue from the Sabang to Merauke area. Religious Activities: Duha prayers in congregation are conducted Monday and Wednesday and Friday from 6:45 a.m. to 7:00 a.m. Extracurricular Activities The distribution of free rice can be seen in the Scouting and Rohis activities of MAN 1 Students, which are sponsored by various ethnic groups and sects, and the diversity of ethnic groups in intracurricular activities.

Students' understanding of diversity is obtained from social media and literature books to enrich their insights regarding learning material obtained at Madrasah. Understanding the diversity of students is to remain tolerant of the existing Tribe, Religion, Race, and Culture without leaving the understanding of each student. Another thing that is not less important is the variety of experiences of students inside and outside the madrasah which makes their diverse views broad and becomes more tolerant.

It is fitting for all parties to provide material and moral support to the activities of the Intra Madrasah Student Organization (OPDIM) which become facilitators in developing talents and interests, one of which is Islamic spiritual activities consisting of several schools, Wahdah, Salafih, NU, Jamaah Tabliq, Muhammadiyah which can be used as role models, mutual understanding and respect for the flow or religious understanding brought by each student that can create tolerance for the plurality of schools that develop in madrasas and understand religious diversity in society.

\section{References}

[1] Adelbert Snijders, 2006. Manusia dan kebenaran. Kanisius. Yogjakarta.

[2] Alex, Dungkal dkk. 2018. Pemikiran, Pergulatan Dr. Jan Riberu: Pendidikan, Relasi Agama-Negara dan Pancasila. Yayasan Flores Abdi Bangsa. Jakarta

[3] Anas, Sudijono, 2011. Pengantar Evaluasi Pendidikan, Jakarta: Rajawali Pers, 2011

[4] Anwar, Choirul. 2018. Islam Dan Kebhinekaan Di Indonesia: Peran Agama Dalam Merawat Perbedaan, Jurnal Pemikiran Islam 'Zawiyah' Volume 4 No. 2 Desember 2018. Hal. 1-18.

[5] Asmani, Jamal Ma'mur, 2012. Buku Panduan Internalisasi Pendidikan Karakter di Indonesia, Jogjakarta: Diva Press.

[6] Bloom Benyamin. 1956 Taxonomy of Educational Objectives, New York: David Mc.Kay

[7] Chaney, David. 1996. Lifestyle: Sebuah Pengantar Konprehensif. Jalasutra. Bandung.

[8] Departemen Pendidikan Nasional, 2008. Kamus Bahasa Indonesia, Jakarta: Pusat Bahasa.

[9] Elly M Setiadi .2006. ilmu sosial dan budaya dasar, jakarta kencana prenada medya group. Cetakan 1.

[10] Harahap, Syahrin. 2012, Teori Kerukunan. Jakarta; Prebada Media.

[11] Hartono, Agung. 2010. menggugah Kesadaran nasional Mempengaruhi Kebhinekaan Indonesia , Jurnal Pendidikan Sosiologi dan humaniora Vo. 1 No. 2 Oktober 2010. Hal. 132-147.

[12] Ismail, Faisan 2012, Republik Bhineka Tunggal Ika, Mengenai Isu-isu Konflik, multikulturalisme, agama dan Sosial Budaya: Jakarta; Badan Litbang dan Kementerian Agama RI.

[13] Lestari, Gina. 2015. Bhinnekha Tunggal Ika: Khasanah Multikultural Indonesia Di Tengah Kehidupan Sara Jurnal Pendidikan Pancasila dan Kewarganegaraan, Th. 28, Nomor 1, Pebruari 2015, Hal. 31-37

[14] L.Eck ,Diana.2006. What is Pluralism?, http//pluralism.com. Diakses tanggal 5 April 2016

[15] Langgulung, Hasan, 2003, Azas-azas Pendidikan Islam, Jakarta; Pustaka Al Husna; Cet-IV

[16] Muslich, Masnur, 2011. Pendidikan Karakter: Menjawab Tantangan Krisis Miltidimensional, Jakarta: Bumi Aksara.

[17] Pi'i (2017), Penanaman Nilai-Nilai Kebhinekaan Melalui Pembelajaran Sejarah Sma. Jurnal SEJARAH DAN BUDAYA, Tahun Kesebelas, Nomor 2, Desember 2017 hal. 180-191 
[18] Retno, Utari 2006, Taksonomi Bloom; Apa dan Bagaimana Menggunakannya, http//setibudi.ac.id/ di akses pada tanggal 21 April 2018

[19] Salim, Haitami.2012. "Menggagas Pendidikan Agama Lintas Sekolah Berciri Khaskan Agama Yang Tidak Seagama”, Dalam Jurnal Analisi, Vol.12 No.2, Desember 2012.

[20] Shofa, Abd Mu'id Aris Shofa, 2016. Memaknai Kembali Multikulturalisme Indonesia Dalam Bingkai Pancasila, Jurnal Pancasila dan Kewarganegaraan, Vol. 1, No. 1, Juli 2016 ISSN 2527-7057 hal. $34-40$

[21] Suardi, Moh.2015, Ideologi Politik Pendidikan Kontenporer, Yogyakarta; The Publish.

[22] Suhady, Idup dan A.M.Sinaga, Wawasan Kebangsaan Dalam Kerangka NKRI, Jakarta; Lembaga Administrasi Negara RI, 2006.

[23] Suparlan, Parsudi. 2003. Bhinneka Tunggal Ika: Keanekaragaman Sukubangsa atau Kebudayaan? Jurnal Antropologi Indonesia 72 tahun 2003. Hal. 24 - 37

[24] Syafri, Ulil Amri. 2012. Pendidikan Karakter Berbasis Al-Quran. Jakarta: Rajagrafindo Persada.

[25] Sudjangi, Bingkai Sosio kultural kehidupan Antar umat Beragama di Indonesia, (Jakarta, Pus Litbang, Depag RI, 1998)

[26] Setiadi dkk, Ilmu Sosial dan Budaya Dasar 2006 (Jakarta Kencana predana Media Group) Voltiere, 2004. Traktak Toleransi. LkiS. Yogjakarta.

[27] Walzer, Michael, 1997. On Toleration, New Haven and London: Yale University Press.

[28] Yusuf Anas, 2009 Managemen Pembelajaran dan Instruksi Pendidikan. Yogyakarta: Ircisod

[29] Zuriah, Nurul. 2005. Metodologi Penelitian Sosial dan Pendidikan; Teori dan Aplikasi. PT Bumi Aksara. Jakarta. 